\title{
THE EMPLOYEE CAPITAL PLANS AS AN ELEMENT OF COMPLEMENTARITY OF THE PENSION SYSTEM IN POLAND
}

\section{ELŻBIETA OCIEPA-KICIŃSKA, ${ }^{1}$ DAWID DAWIDOWICZ ${ }^{2}$}

\author{
${ }^{1}$ University of Szczecin, Faculty of Management and Economics of Services, POLAND \\ e-mail: elzbieta.ociepa-kicinska@wzieu.pl \\ ${ }^{2}$ West Pomeranian University of Technology, in Szczecin, Faculty of Economics, POLAND \\ e-mail: dawid.dawidowicz@zut.edu.pl
}

\begin{tabular}{l|l} 
RECEIVED & 6 November 2018 \\
ACCEPTED & 3 December 2018 \\
JEL & \\
CLASSIFICATION & E21, E61
\end{tabular}

KEYWORDS pension system, retirement savings, pension awareness, employee capital programs

ABSTRACT The pension system in Poland in recent years has been strongly reformed. The idea of a three-pillar system operating on the basis of a mandatory capital pillar did not last even two decades. As a result, the mandatory part of the pension system is based solely on the principle of repartition, and at the same time the economic and demographic situation of the country should lead to retirement savings. Unfortunately, the awareness of Poles in this area is negligible. Subsequent changes introduced so far have not been an effective incentive to significantly popularize voluntary forms of accumulating pension savings. This situation is to be changed by the introduction of voluntary and at the same time common employee capital programs. The study analyzed the basis of the introduced changes and the construction of the Employee Capital Plans (Pracownicze Programy Kapitałowe-PPK). On this basis, the principles of the functioning of the PPK were compared with the remaining solutions of the second and third pillar of the Polish pension system. This analysis allowed for the formulation of opportunities and threats resulting from the launch of a new financial tool in the form of a PPK. The main goal of the article was to analyze the third pillar of the pension system, including Employee Capital Plans. PPK supplements the third pillar of the pension system. On the one hand, a new form of saving gives the chance to accumulate more savings for future retirees but on the other hand, does not guarantee the collection of sufficient funds for them. Moreover the voluntary nature of this form may not protect the interest of all employees in Poland. The noticeable effect for employers will be higher labor costs and lower remuneration for employees.

\section{Introduction}

The pension system is an integral part of the system of social protection, and its goal is to prevent a sharp drop in income and protection against poverty based on age, people disability or death (Holzmann, 2012, p. XIII). In the 70's and 80's of the XX century, the accumulated effect of the post-war birth summit and the constantly increasing average life span of people began to affect the system's efficiency (Ambachtsheer, Ezra, 2001, p. 239). 
This trend meant that in the 80's and 90's the construction of legal and financial pension insurance had proved to be inefficient financially (Sowiński, 2009, p. 116). Therefore, it was necessary to make changes, which the main idea was to relieve the system based on the principle of apportionment in favor of solutions based on the capital market. In Poland, in 1999 it was carried out pension reform, which resulted in a three-pillar system, which the main advantage was to be the mandatory second pillar based on the capital market. At the same time, both economists and politicians invariably emphasize the need for widespread forms of voluntary retirement savings accumulate in Poland. Due to the deteriorating situation continues demographic and relatively little interest in the voluntary pillar of the pension system 19th of November 2018 the President signed the law on Employee Capital Plans (Pracownicze Programy Kapitałowe - PPK), which have the chance to be an effective complement-existing pension system in Poland. The aim of the study is to analyze the changes and substrate construction of PPK, PPK comparison of the principles of operation of other solutions, the second and third pillar of the Polish pension system and to analyze the opportunities and threats arising from the introduction of the new financial instrument in the PPK form.

\section{The reasons for introducing of Employee Capital Plans}

According to the assumptions made in Poland in 1999 (Ustawa o organizacji i funkcjonowaniu funduszy emerytalnych, 1997) of the reform of the pension system, the first pillar based on the principle of repartition, II-nd pillar were open pension funds (Otwarte Fundusze Emerytalne - OFE) managed by the Universal Pension Societies (Powszechne Towarzystwa Emerytalne - PTE)), while the third pillar covered all voluntary forms of accumulation of retirement savings, primarily: employee pension schemes (Pracownicze Programy Emerytalne - PPE), individual pension accounts (Indywidualne Konta Emerytalne - IKE) and individual retirement accounts (Indywidualne Konta Zabezpieczenia Emerytalnego - IKZE) (Figure 1).

\begin{tabular}{|c|c|c|}
\hline \multicolumn{2}{|c|}{ Pension system in Poland } \\
\hline $\begin{array}{c}\text { Social Insurance Institution - } \\
\text { Social Insurance Fund }\end{array}$ & $\begin{array}{c}\text { The second capital pillar } \\
\text { Universal Pension Societies - } \\
\text { Open Pension Funds }\end{array}$ & The third capital pillar \\
Agricultural Social Insurance Fund & Employee Pension Programs \\
Individual Pension Accounts \\
Individual Retirement Accounts
\end{tabular}

Figure 1. Pension system in Poland in 2018

Source: own study.

Participation in OFE was compulsory for people born from 1st of January 1969. The pension contribution rate of $19.52 \%$ of the contribution assessment base was divided between Social Insurance Institution and OFE, as a result of which $7.3 \%$ of the contribution base was transferred to the OFE. The rules of OFE operation have been changed many times, finally from 1st of August 2014 participation in OFE is voluntary, as a result of which professionally active people themselves decide whether their pension contribution will be transferred in full to Social Insurance Institution or shared between Social Insurance Institution and OFE. In the case of the participant's 
pension decisions about the desire of belonging to pension funds on his/her account at the second pillar is drained premium of $2.92 \%$ of the base.

In addition to change in the obligatory participation in the second pillar, 3th of February $2014,51.5 \%$ were discontinued accounting units (expressed in PLN contractual units of share in the net value of OFE) accumulated by OFE members, transferred them to the Ist pillar (Ustawa o zmianie niektórych ustaw w zwiazku z określeniem..., 2013). These changes have led to the marginalization of the mandatory capital part of the pension system. At the same time, few people benefit from voluntary solutions, which is a derivative of the low awareness of Poles pensions. From the results of the TNS Polska research as part of the Polish tendency for additional saving for retirement project - is it myth or reality? (TNS Polska, 2016) published in 2016 shows that only 14\% of Poles aged 25-45 declare that they also save for retirement. Adamska-Mieruszewska and Mosionek-Schweda (2015), stress that the lacks of society knowledge about the possibilities of investing under the third pillar, and there is no culture of long-term saving. Rutecka-Góra and Cichowicz (2017) indicate that one of the most important factors is the level of awareness and knowledge about collecting savings for this purpose.

In 2016, the Social Insurance Institution carried out a review of the Pension System. Security thanks to responsibility, which was the basis for the development of the Green Book (Zielona Ksiega..., 2016), containing a diagnosis of the pension system and an assessment of the functioning of the pension insurance, which shows that $75 \%$ of Poles do not put their money down in old age, giving as a reason the lack of sufficient funds for this purpose or their lack. On this basis, the White Paper (Biała księga..., 2016) was created containing recommendations for reforms regarding the broadly defined pension security. The creation of the Employee Plans Capital will be a partial answer to the problems of the future.

\section{The main assumptions of the principles of the Employee Capital Plans}

PPKs should be a supplement the pension, thus translating into an increase in the level of security for future pensioners, which will affect the higher standard of living of Poles in old age. Detailed rules for the functioning of the PPK are set out in the Act of 4th of October 2018 on employee capital plans. They are characterized primarily by:

1. To encourage the dissemination of systematic collection of savings with the main purpose of the payment by the PPK participant after reaching 60 years of age.

2. Universality - each entity employing at least one person is obliged to conclude an agreement on the management of PPK.

3. Voluntarily - at any time PPK participant may opt out of making payments to the PKK on the basis of a declaration of the entity that employs writing.

4. Three sources of payments - basic, additional and bonus deposits are found in PPK:

a) basic payments are funded by the employing entity and participant PPK from its own resources. The basic payment funded entity employing $1.5 \%$ of salary, and funded by the participant PPK is $2 \%$ of salary (or is within the range of $0.5 \%-2 \%$ when payment participant PPK derived from different sources in a given month does not exceed corresponding to 1.2 times the minimum remuneration);

b) additional payments - the employing entity may declare an additional payment of up to $2.5 \%$ of remuneration. The participant may declare an additional payment of up to $2 \%$ of remuneration;

c) the bonus payments financed by the Labor Fund - welcome single payment in the amount of 250 PLN and annual additional payment in the amount of 240 PLN recorded on the account PPK. 
5. Rational investment policy - entities managing funds accumulated on PPK accounts will locate them in the so-called defined dated funds which will base their investment policy on the remaining period of the pensioner's retirement. Additionally, the legislator defines detailed minimum and maximum investment limits for individual categories of financial instruments.

6. Reducing PPK management costs - the maximum level of asset management fees can not be higher than $0.5 \%$ of the net asset value of the fund/sub-fund per annum. These entities may also collect remuneration for the achieved result, at a level no higher than $0.1 \%$ of the net assets of the fund/sub-fund per annum.

7. The ability to withdraw funds - the participant may at any time resign from participation in the PPK, he/she may also withdraw some of them in justified life situations described in the Act.

8. Four types of entities authorized to hold PPK accounts: investment fund societies, general pension societies, employee pension companies and insurance companies.

9. Launching in stages - from $1^{\text {st }}$ of July 2019 for entities which employ at least 250 people, from $1^{\text {st }}$ of January 2020 for entities employing at least 50 people, from $1^{\text {st }}$ of July 2020 for entities employing at least 20 people, from $1^{\text {st }}$ of January 2021 for other entities and persons employed in units of the public finance sector.

10. No obligation to introudce the PPK:

a) employers who on the date of entry into force of the law on PPK offer their employees EPP, carrying away part of its contribution to the level of at least $3.5 \%$ of the assessment base;

b) microentrepreneurs, who all employees unanimously and voluntarily forego the desire to participate in the PPK.

Such a PPK construction has to constitute the basis for a radical change in the universality of voluntary pension savings in Poland, thus translating into the amount of retirement benefits after retirement age.

\section{The PPK comparison with existing programs II-nd and III-pd pillar pension system in Poland}

The PPE is a voluntary form of group saving for retirement, organized by the employer with the participation of employees (Ustawa o pracowniczych programach emerytalnych), while IKE and IKZE are accounts for accumulating pension savings, where the payment is made directly by the holder of the account. The OFE from the obligatory pillar of the capital system have become its marginal, voluntary fragment. In the Table 1 shows a comparative analysis of the most important features of OFE, IKE, IKZE and PPE. Comparing the structure listed in Table 1 elements Polish pension system with the idea of PPK, it can be seen that:

a) the common feature of PPK, IKE, IKZE, PPE and OFE and pension funds is voluntary participation in the program can also be the holder of each of these solutions at the same time;

b) substantial difference between the PPK and other solutions is the principle of automatic subscription to PPK (without additional activity of an employee);

c) there are deposit limits in each of the solutions (except OFE);

d) funds accumulated in each of the analyzed solutions are subject to inheritance;

e) for OFE and PPK, the legislator has defined investment limits affecting for the structure of the portfolio of assets in which the savings of their members are invested;

f) for OFE and PPK, the legislator determined the maximum level and type of fees. 
Table 1. Analysis of financial tools of the second and third pillar of the pension system in Poland operating in 2018.

\begin{tabular}{|c|c|c|c|c|}
\hline & OFE & IKE" & IKZE & PPE \\
\hline Number of entities & 10 PTE & 55 financial institutions & 41 financial institutions & $\begin{array}{l}\text { 1,536 registered PPE, } \\
\text { included } 1,053 \text { active }\end{array}$ \\
\hline $\begin{array}{l}\text { The size of managed } \\
\text { assets }\end{array}$ & PLN 158.1 billion & PLN 8.2 billion & PLN 8.2 billion & PLN 12.6 billion \\
\hline Number of members & $15,997.1$ thousand & 960.5 thousand & 767.7 thousand & 395.8 thousand \\
\hline Premium level & $2.92 \%$ of the calculation base & Any within the deposit limit & Any within the deposit limit & $\begin{array}{l}\text { Financed by the employer: } \\
\text { up to } 7 \% \text { of the calculation } \\
\text { basis plus voluntary } \\
\text { employee contributions }\end{array}$ \\
\hline Premium financing & $\begin{array}{c}\text { Financed from the part } \\
\text { of the compulsory pension } \\
\text { contribution }\end{array}$ & $\begin{array}{l}\text { Directly participant of the } \\
\text { program }\end{array}$ & $\begin{array}{l}\text { Directly participant of the } \\
\text { program }\end{array}$ & $\begin{array}{l}\text { Employer or employer } \\
\text { and employee }\end{array}$ \\
\hline Deposit limit in 2018 & - & PLN 13,329 & PLN 5,331.60 & $\begin{array}{c}\text { PLN 19,993.50 (applies } \\
\text { to voluntary employee } \\
\text { contributions) }\end{array}$ \\
\hline Investment limits & Yes & No & No & No \\
\hline
\end{tabular}

'Data as at the end of the second quarter of 2018.

"Data as at the end of the second quarter of 2018.

Source: own study based on: OFE zarządzane... (2018); Rynek OFE w II kwartale.. (2018); Ustawa z dnia 20 kwietnia 2004 r. o PPE (2016); PPE w 2017... (2018); IKE oraz IKZE...(2018).

\section{The opportunities and pisks associated with the launching of the Employee Capital Plans}

PPK create a real opportunity to increase the funds collected by the Poles to retire. Despite the voluntary participation in the program, auto-save mechanism should provide a good basis for the spread of this form of pension savings. So far, all other programs of the third pillar were related to the need for additional activity on the part of the employee who wanted to participate in the program. PPE may be "competitor" for the PPK - employers are not obliged to launch a PPK until the entry into force the PPK Act, they meet the following three conditions in total:

a) set the PPE;

b) pay the basic contributions to PPE in the amount of at least $3.5 \%$ of remuneration;

c) joined to the PPE at least $25 \%$ of employees in the employing entity.

Nevertheless, the number of PPE and the scale of their operation is so small that they should not significantly influence the dissemination of the PPK.

The relatively low amount of the contribution to the PPK and limitations as to its amount may not be sufficient to significantly improve the situation of employees after retirement. Introducing to the PPK construction funds, life cycle, the legislature sought to reduce investment risks and protect the value of assets held in these funds, however, alarmed by the fact that firmly imposed the structure of portfolios of assets in the funds specified date as the sole determinant of changes in the assets side of the lower risk profile takes the number of years remaining until retirement age by its participants, not taking into account the market situation.

A threat to take part in the program are also frequent changes in regulations governing the pension system and the multitude of different solutions. The first fear is uncertainty about the funds collected in the PPK, despite the assurances that these funds will remain private. It is worth to remaind that the funds collected in the second pillar 
were financed only from private funds, ie from the employee's part and from the employer's contributions, while the change in the law allowed transferring half of the funds collected in the OFE to the Social Insurance Fund. Frequent changes in the law in recent years may cause public distrust about the new form of saving.

The consequence of the introduction of the PPK will be a greater burden on employers of the costs of contributions paid into the program, and allowing the employer to include the amount of premiums into the costs of income will reduce the tax revenue on this account to the state budget. In addition, the consequence of participation in the PPK for employees will reduce disposable income as part of their remuneration shall be deducted the amount of the premium.

The controversial risk element regarding the PPK is a relatively strictly defined amount of the maximum costs of participation in the program, which will be charged by the institutions which offer PPK. On the one hand it aims to protect the interests of participants in the program, but it can also affect a small number of PPK offered on the market due to the lack of profitability of their conduct, in particular, in the initial period of their operation.

\section{Conclusions}

PPK is next element of the third pillar of the pension system in Poland. Its implementation may contribute to the collection of more funds for future retirement, however, the organization of the PPK is also associated with risks related to, among others the voluntary nature of this form of saving, the sufficiency of contributions paid in this form, the cost-effectiveness of creating PPK by financial institutions on the market, etc. The establishment of the PPK does not solve the biggest problem related to saving, i.e. the lack of sufficient knowledge and awareness of the necessity of saving for future retirement and the lack of sufficient free resources available for saving and distrust of the pension system caused by relatively often changing legal regulations.

The effect of the introduction of the PPK will also increase employee costs and reduce employee salaries.

\section{References}

Adamska-Mieruszewska, J., Mosionek-Schweda, M. (2015). Rozwój indywidualnych oszczędności emerytalnych w kontekście skłonności Polaków do oszczędzania. Retrieved from: www.pwe.com.pl/files/723397080/file/1_rozwoj_indywidualnych_ oszczednosci.pdf.

Ambachtsheer, K.P., Ezra, D.D. (2001). Fundusze emerytalne - jak efektywnie pomnażać majątek ich członków. Kraków: Dom Wydawniczy $A B C$.

Biała księga (2016). Przegląd Systemu Emerytalnego. Bezpieczeństwo dzięki odpowiedzialności 2016. Warszawa: Zakład Ubezpieczeń Społecznych.

Holzmann, R., Palmer, E., Robalino, D. (2012), Nonfinancial DC Pension Schemes in a Changing Pension World, Volume 1: Progress, Lessons and Implementation. The World Bank.

IKE oraz IKZE w 2017 roku (2018). Warszawa: Komisja Nadzoru Finansowego.

OFE zarządzane przez PTE (2018). Retrieved from: www.knf.gov.pl/podmioty.

PPE w 2017 roku (2018). Warszawa: Komisja Nadzoru Finansowego.

Rutecka-Góra, J., Cichowicz, E. (2017). Świadomość Polaków dotycząca dodatkowego oszczędzania na starość - próba oceny oraz identyfikacji niezbędnych działań. Retrieved from: www.researchgate.net/publication/320126090.

Rynek OFE w II kwartale 2018 roku (2018). Warszawa: Komisja Nadzoru Finansowego.

Sowiński, T. (2009). Finanse ubezpieczeń emerytalnych. Kraków: Oficyna a Wolters Kluwer business.

TNS Polska (2016). Skłonność Polaków do dodatkowego oszczędzania na emeryturę - mit czy rzeczywistość? Retrieved from: www. tnsglobal.pl/coslychac/files/2016/03/Sklonnosc-do-oszczedzania-na-emeryture-2016-03-04.pdf.

Ustawa o organizacji i funkcjonowaniu funduszy emerytalnych z dnia 28 sierpnia 1997 roku, Dz.U. z dnia 20 listopada 1997. 
Ustawa z dnia 20 kwietnia 2004 r. o PPE. Dz.U. 2016, poz. 1449.

Ustawa z dnia 25 marca 2011 r. o zmianie niektórych ustaw związanych z funkcjonowaniem systemu ubezpieczeń społecznych, Dz.U. nr 75, poz. 398.

Ustawa z dnia 4 października 2018 r. o PPK, art. 2, ust. 40.

Ustawa z dnia 6 grudnia 2013 r. o zmianie niektórych ustaw w związku z określeniem zasad wypłaty emerytur ze środków zgromadzonych w otwartych funduszach emerytalnych. Dz.U. poz. 1717.

Zielona księga (2016). Przegląd Systemu Emerytalnego. Bezpieczeństwo dzięki odpowiedzialności 2016. Warszawa: Zakład Ubezpieczeń Społecznych.

Cite this article aS: Ociepa-Kicińska, E., Dawidowicz, D. (2018). The Employee Capital Plans as an element of complementarity of the pension system in Poland. European Journal of Service Management, 4 (28/1), 231-237. DOI: 10.18276/ejsm.2018.28/1-29. 